\title{
Manufacture of reduced-sodium Cheddar-style cheese with mineral salt replacers
}

\author{
J. Grummer, M. Karalus, K. Zhang, Z. Vickers, and T. C. Schoenfuss ${ }^{1}$ \\ Department of Food Science and Nutrition, University of Minnesota, Saint Paul 55108
}

\begin{abstract}
The use of mineral salt replacers to reduce the sodium content in cheese has been investigated as a method to maintain both the salty flavor and the preservative effects of salt. The majority of studies of sodium reduction have used mineral salt replacers at levels too low to produce equal water activity $\left(\mathrm{a}_{\mathrm{w}}\right)$ in the finished cheese compared with the full-sodium control. Higher $\mathrm{a}_{\mathrm{w}}$ can result in differences in cheese quality due to differences in the effective salt-to-moisture ratio. This creates differences in biochemical and microbial reactions during aging. We hypothesized that by targeting replacer concentrations to produce the same $a_{w}$ as full sodium cheese, changes in cheese quality would be minimized. Stirred-curd Cheddar-style cheese was manufactured and curd was salted with $\mathrm{NaCl}$ or naturally reduced sodium sea salt. Reduced-sodium cheeses were created by blends of $\mathrm{NaCl}$ or sea salt with $\mathrm{KCl}$, modified $\mathrm{KCl}, \mathrm{MgCl}_{2}$, or $\mathrm{CaCl}_{2}$ before pressing. Sodium levels in reduced-sodium cheeses ranged from 298 to $388 \mathrm{mg}$ of sodium/100 g, whereas the control fullsodium cheese had $665 \mathrm{mg} / 100 \mathrm{~g}$. At 1 wk of age, $\mathrm{a}_{\mathrm{w}}$ of reduced-sodium cheeses were not significantly different from control, which had an $\mathrm{a}_{\mathrm{w}}$ of 0.96 . The $\mathrm{pH}$ values of all reduced-sodium cheeses, excluding the treatment that combined sea salt and $\mathrm{MgCl}_{2}$, were lower than those of full-sodium cheese, indicating that the starter culture was possibly less inhibited at the salting step by the replacers than by $\mathrm{NaCl}$. Instrumental hardness values of the treatments with sea salt were higher than in cheeses containing $\mathrm{NaCl}$, with the exception of the $\mathrm{NaCl} / \mathrm{CaCl}_{2}$ treatment, which was the hardest. Treatments with $\mathrm{MgCl}_{2}$ and modified $\mathrm{KCl}$ were generally less hard than other treatments. In-hand and first-bite firmness values correlated with the instrumental texture profile analysis results. Both $\mathrm{CaCl}_{2}$ and $\mathrm{MgCl}_{2}$ produced considerable off-flavors in the cheese (bitter, metallic, unclean, and soapy), as measured by descriptive sensory analysis with a trained panel. Bitterness
\end{abstract}

Received August 20, 2011.

Accepted December 20, 2011.

${ }^{1}$ Corresponding author: tschoenf@umn.edu ratings for cheese with $\mathrm{KCl}$ and modified $\mathrm{KCl}$ were not significantly different from the full-sodium control. Potassium chloride can be used successfully to achieve large reductions in sodium when replacing a portion of the $\mathrm{NaCl}$ in Cheddar cheese.

Key words: sodium reduction, cheese, water activity, salt replacer

\section{INTRODUCTION}

Dietary sodium contributes to the development of hypertension, which can be a precursor to conditions such as cardiovascular disease and increases the risk for heart attacks and stroke in some individuals (Appel et al., 2006; Cotugna and Wolpert, 2011). At approximately 615 to $620 \mathrm{mg}$ of sodium/100 g of cheese (Agarwal et al., 2011; USDA, 2011), Cheddar cheese contains approximately $8 \%$ of the US Food and Drug Administration's daily recommended value per serving (FDA, 2011). Cheese was reported to be the second largest contributor in the US diet of known sources of dietary sodium (almost 60\% was from unknown sources) in one report, and dairy products were listed as the fourth largest contributor and reported to contribute $8.2 \%$ of the sodium in the US diet in another report (Jacobson, 2005; Anderson et al., 2010). Therefore, reducing the sodium content of cheese could have significant health benefits for some individuals.

Sodium reduction in natural cheese is inherently difficult due to the desirable effects of salt $(\mathrm{NaCl})$ on flavor, culture activity, syneresis, and enzymatic activity (Guinee, 2004). Replacement salts containing potassium, magnesium, and calcium have been investigated in various cheeses (Lindsay et al., 1982; Fitzgerald and Buckley, 1985; Aly, 1995; Reddy and Marth, 1995; Katsiari et al., 1997, 2001; Johnson et al., 2009; Ayyash and Shah, 2011a,b). The purpose of these mineral salt replacers is to maintain the salty taste as well as enzymatic and microbial stability by maintaining water activity $\left(\mathbf{a}_{\mathrm{w}}\right)$ of the cheese. However, most studies that examined salt replacers did not use them at a high enough concentration to equal the $\mathrm{a}_{\mathrm{w}}$ of full-sodium cheese made with the same make procedure. This could have been because salt replacers have been implicated 
in causing bitter and metallic off-flavors (Lindsay et al., 1982; Fitzgerald and Buckley, 1985). However, clear conclusions about the effect of the salt replacers on taste cannot be made because varying the $a_{w}$ could result in bitterness due to differences in biochemical reactions during aging.

Water activity in young cheese is driven by the saltto-moisture ratio $(\mathbf{S} / \mathbf{M})$, which has numerous other significant effects on cheese aging (Guinee, 2004). However, because of differences in molecular weight, the traditional S/M calculation does not apply when using salt replacers. Biochemical reactions can likely be maintained between full- and reduced-sodium cheese by maintaining the $\mathrm{a}_{\mathrm{w}}$ between treatments due to the close relationship between $\mathrm{a}_{\mathrm{w}}$ and $\mathrm{S} / \mathrm{M}$. Similar biochemical reactions would allow for a clear evaluation of the salt replacers in cheese. Deviations in $\mathrm{a}_{\mathrm{w}}$ from control would be equivalent to deviations in the $\mathrm{S} / \mathrm{M}$ and, therefore, reactions during cheese aging.

We hypothesized that reduced-sodium Cheddar-style cheese could be made with mineral salt replacers, and that by maintaining the $\mathrm{a}_{\mathrm{w}}$ of full-sodium control cheese, the effect of the $\mathrm{S} / \mathrm{M}$ would be simulated and result in similar biochemical reactions during cheese aging. This would eliminate the difference in the reaction rates of microorganisms and enzymes, and the unadulterated effect of the salt replacers could be observed. To test this hypothesis, stirred-curd Cheddar-style cheese was manufactured, and curd was salted with $\mathrm{NaCl}$ or a naturally reduced-sodium sea salt, and reduced-sodium cheeses were created with blends of $\mathrm{NaCl}$ or sea salt with $\mathrm{KCl}$, modified $\mathrm{KCl}, \mathrm{MgCl}_{2}$, or $\mathrm{CaCl}_{2}$ before pressing. Salt and salt replacers were applied at concentrations to achieve an equivalent $\mathrm{a}_{\mathrm{w}}$ to that of full-sodium cheese, and the cheese was evaluated for chemical, physical, and sensory differences.

\section{MATERIALS AND METHODS}

\section{Cheese Making Materials}

Lactococcus lactis ssp. cremoris and Lc. lactis ssp. lactis (CHOOZIT Superstart direct-to-vat-set strain M30, Danisco USA Inc., Madison, WI), annatto (AFC W/S 1X 70463, Chr. Hansen Inc.), 45\% (wt/vol) calcium chloride (CAL-SOL 71257, Chr. Hansen Inc.), and liquid chymosin (CHY-MAX 73863, Chr. Hansen, Inc., Milwaukee, WI) were used to manufacture the cheese.

Sodium chloride (Top-Flo Evaporated Salt, Cargill Inc., Minneapolis, MN) and the salt replacers KCl (Premier Potassium Chloride 8799, Cargill Inc.), a modified $\mathrm{KCl}$ (Modified Potassium Chloride 14510, Nu-Tek Products Inc., Minnetonka, $\mathrm{MN}$ ), $\mathrm{MgCl}_{2}$ (magnesium chloride 6-Hydrate 5956-06, Mallinckrodt Baker Inc.,

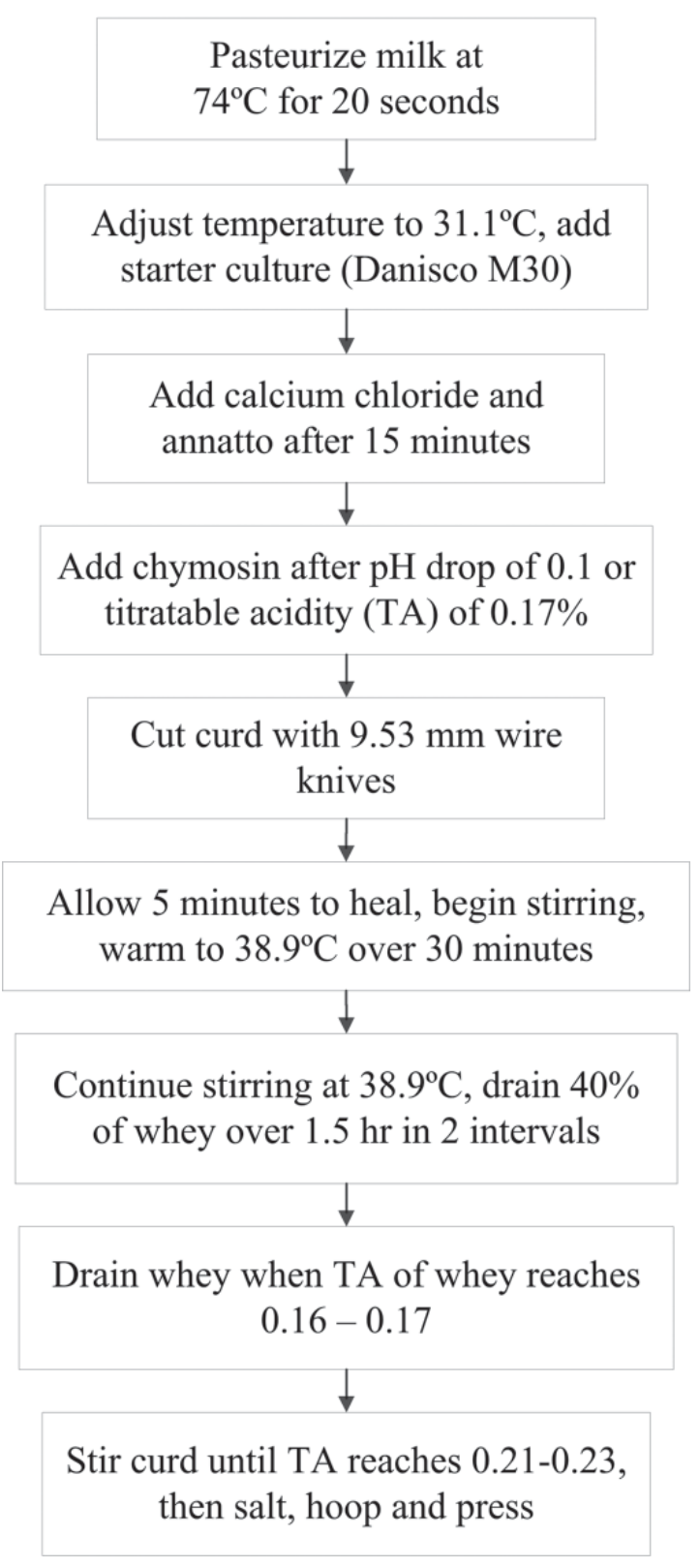

Figure 1. Flow diagram of the cheese making procedure.

Phillipsburg, $\mathrm{NJ}$ ), $\mathrm{CaCl}_{2}$ (calcium chloride dihydrate, granular 4616-06, Mallinckrodt Baker Inc.), and a $45 \%$ reduced-sodium sea salt (SS45, A\&B Ingredients, Fairfield, NJ) were used to salt the cheese curd. The percentage composition of the sea salt listed on the ingredient specification was as follows: sodium $22.0 \pm$ 0.6 , chloride $34.0 \pm 0.9$, sulfate $23.0 \pm 0.7$, potassium $9.0 \pm 0.3$, magnesium $2.0 \pm 0.1$, trace elements 0.3 , and moisture $10.0 \pm 1.5$. The percentage of salts present in the chloride or sulfate form was not specified. All were Food Chemicals Codex (FCC) or United States Pharmacopeia (USP) grade. 
Table 1. Percentage of salt and salt replacers applied to drained curd (wt/wt) ${ }^{1}$

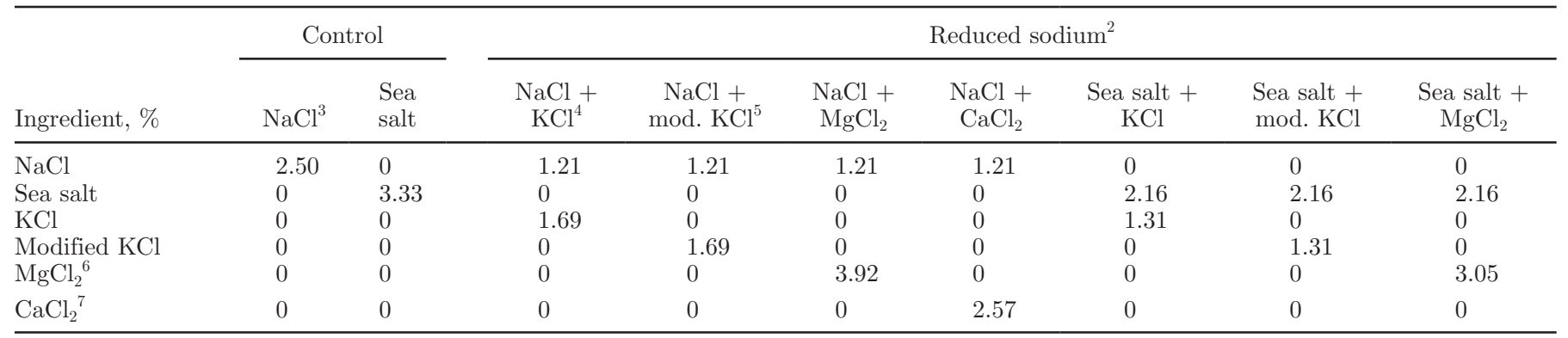

${ }^{1}$ Target amounts took into account expected loss during salting and pressing.

${ }^{2}$ Target: $300 \mathrm{mg}$ of sodium/100 g.

${ }^{3}$ Target: $640 \mathrm{mg}$ of sodium/100 g.

${ }^{4}$ Premier Potassium Chloride 8799 (Cargill Inc.).

${ }^{5}$ Modified Potassium Chloride 14510 (Nu-Tek Products Inc., Minnetonka, MN).

${ }^{6}$ Magnesium chloride 6-hydrate.

${ }^{7}$ Calcium chloride di-hydrate.

\section{Cheddar-Style Cheese Manufacture}

Cheddar-style cheese was manufactured at the University of Minnesota's Joe Warthesen Food Processing Center (St. Paul, MN ). Raw whole milk was pasteurized at $74^{\circ} \mathrm{C}$ for $20 \mathrm{~s}$ on a Cherry-Burrell $1800 \mathrm{~kg} / \mathrm{h}$ plate and frame-style milk pasteurizer (SPX, Delavan, WI) and pumped into a Damrow 2,260-kg rectangular vat (Tetra Damrow, Vernon Hills, IL) at $31.1^{\circ} \mathrm{C}$. Cheese making proceeded as described in Figure 1. The majority of the remaining whey was drained once the titratable acidity reached 0.16 to 0.17 (lactic acid basis); enough whey was maintained in the vat to prevent the curd from drying. Curd was stirred until the titratable acidity reached 0.21 to 0.23 , at which point the drained curd was weighed into individual plastic bins with drain holes and salted in 3 additions. The percentages of salt and salt replacers applied to the drained curd are shown in Table 1 . These amounts were determined by calculation (taking account the hydration state of the minerals), and confirmed and adjusted using a model system on a water activity meter as described in Grummer and Schoenfuss (2011). A final sodium chloride concentration of $1.6 \%$ and moisture of $37 \%$ were the targets for the equivalent $\mathrm{a}_{\mathrm{w}}$ we wanted to achieve (target was our full-sodium control cheese). The sea salt used had less sodium and a higher use rate was needed to achieve the same $a_{w}$, as shown in Table 1 . The blends of salts were added in 3 additions spaced 5 min apart, and curd was stirred continuously by hand. Curd was transferred to cheesecloth-lined, 9.1-kg Wilson-style cheese hoops and pressed overnight at $276 \mathrm{kPa}$. Blocks were vacuum packaged and stored at 4 to $5^{\circ} \mathrm{C}$. Cheese making was replicated on $2 \mathrm{~d}$ with different lots of milk. These replicates will be referred to as batches.

\section{Compositional and Chemical Analysis}

Fat and ash were determined by standard methods 18.8A2c and 18.4A, respectively (Richardson, 1985). Moisture was determined by vacuum oven following standard method 15.111 (Wehr and Frank, 2004). Water activity was measured at $23^{\circ} \mathrm{C}$ on an Aqua Lab 3TE $\mathrm{a}_{\mathrm{w}}$ meter (Decagon Devices, Pullman, WA). The $\mathrm{pH}$ was measured with an Acorn $\mathrm{pH} 6$ Meter (Oakton Instruments, Vernon Hills, IL) with an Orion Ross Sure-Flow pH electrode (Thermo Fisher Scientific Inc., Waltham, MA). Total protein (total nitrogen $\times 6.38$ ) was determined using a TruSpec N (Leco Corp., St. Joseph, MI) based on the Dumas method of combustion. Sodium, potassium, magnesium, and calcium content were measured by atomic absorption spectrometry using a Perkin Elmer AAnalyst 100 using IDF method 119:2007(E) (IDF, 2007) with the exception of using the hot plate wet ashing digestion time and temperature of Kira et al. (2004). All measurements were performed in duplicate, at minimum.

\section{Texture Profile Analysis}

Instrumental texture profile analysis (TPA) was performed on a TA.XTPlus texture analyzer (Texture Technologies Corp., Scarsdale, NY). Instrumental hardness, springiness, cohesiveness, adhesiveness, resilience, and chewiness were calculated according to Bourne (1978). Cheese was equilibrated to $7^{\circ} \mathrm{C}$ for $16 \mathrm{~h}$ before cylinders (11.75 $\mathrm{mm}$ in diameter, $50-60 \mathrm{~mm}$ high) were cut with a steel cork borer and placed in an air-tight bag. Multiple samples of $12 \mathrm{~mm}$ height were cut from the cylinders, excluding $5 \mathrm{~mm}$ on each end, using a guided blade and returned to the bag. Samples were individually removed from the refrigerator, and a thin 
layer of light white mineral oil (151694, MP Biomedicals LLC, Solon, OH) was applied to both ends. Within $20 \mathrm{~s}$ of removal, samples were compressed twice, with $2 \mathrm{~s}$ between compressions, to $20 \%$ of original height at a crosshead speed of $1 \mathrm{~mm} / \mathrm{s}$ between a 25 -mm-diameter polycarbonate probe (TA11, Texture Technologies Corp.) and a polycarbonate stage; room temperature was $23^{\circ} \mathrm{C}$. A minimum of 5 replicates per cheese sample was analyzed.

\section{Statistical Analysis of Compositional, Chemical, and Texture Profile Analyses}

We used an ANOVA (Linear Mixed Model analysis, SPSS Statistics ver. 17.0.2, IBM SPSS, Chicago, IL) to determine whether cheese treatments differed in any of these measurements. We used Fisher's Least Significant Difference to determine whether specific cheese treatments differed from each other.

\section{Descriptive Sensory Analysis}

Subjects. Nine members of the trained panel from the Sensory Center at the University of Minnesota (St. Paul ) participated in these tests. All were 6- $n$ propylthiouracil (PROP) tasters or supertasters and were compensated for participating. Each had at least $20 \mathrm{~h}$ of training before starting this study. All recruiting and experimental procedures were approved by the University of Minnesota's Institutional Review Board.

Training. Panelists participated in five 1-h training sessions in which a lexicon of sensory attributes and references (Supplemental Table 1; http://www. journalofdairyscience.org/) was collectively developed and refined. Taste, flavor, aroma, and texture attributes and references used for the descriptive sensory analysis are listed in the lexicon. Cheese samples used for this training were a subset of cheeses used in this study, selected to represent the range of differences the subjects would find during the testing. Food Chemicals Codex or United States Pharmacopeia grade. Panelists practiced evaluating the cheeses on SIMS Sensory Evaluation Software (Sensory Computer Systems, Morristown, NJ), which was used during testing. Results were discussed as a group. Practice sessions were repeated to finalize the lexicon.

Products and Testing. Fourteen cheeses were included: 7 treatments from 2 cheese batches. Panelists received 3 cubes $\left(1.5 \mathrm{~cm}^{3}\right)$ of each cheese at room temperature $\left(22^{\circ} \mathrm{C}\right)$ in a random 3 -digit-coded $120-\mathrm{mL}$ plastic cup with a lid.

Panelists participated in 4 test sessions. Panelists evaluated a complete set of the samples from the first batch in the first 2 sessions (the second session served as

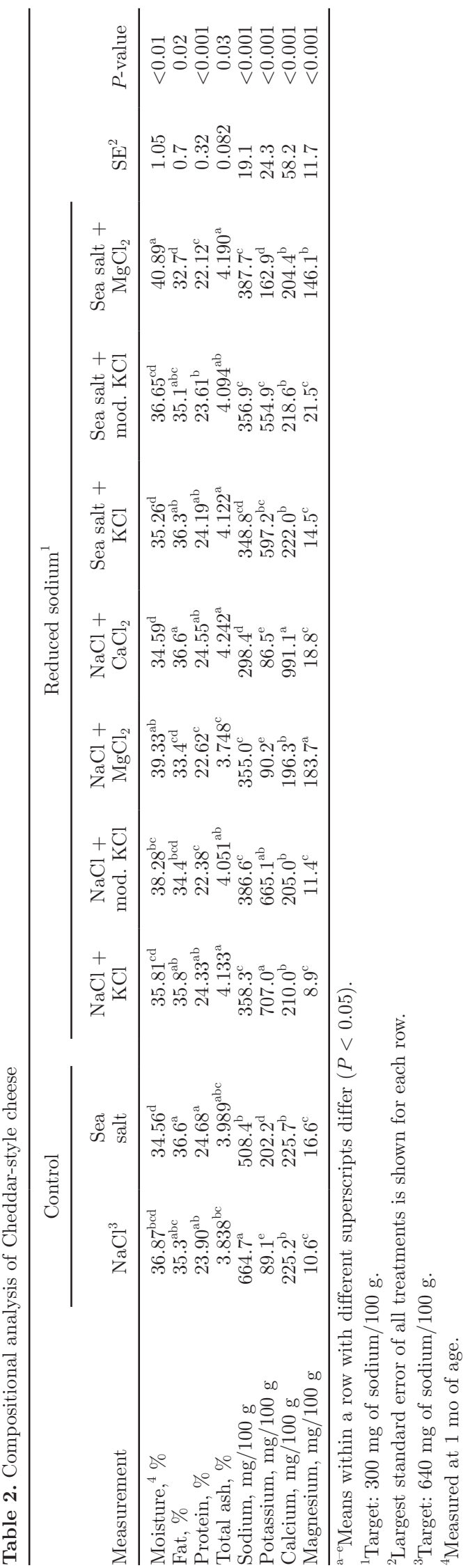

Journal of Dairy Science Vol. 95 No. 6, 2012 
a sensory replicate) and a complete set of the samples from the second batch in the third and fourth sessions (the fourth session served as the sensory replicate). Within a session, serving order was balanced for order and carryover effects. During the testing sessions, each panelist evaluated each sample by rating the intensity of the attributes on a 20-point line scale labeled "none" at the left end and "intense" at the right end. Intensity ratings of flavor and taste were made on the standard citric acid scale (Pontet et al., 2010). Ratings of odors were made on the standard butanol scale (ASTM, 2010). Texture ratings were made on a 20 -point scale anchored with references. Panelists were instructed to wear nose clips when evaluating the taste attributes.

Data Analysis. We used ANOVA (SAS PROC GLM ver. 9.1 (SAS Institute Inc., Cary, NC) to determine which sensory attributes differed significantly among the products. The sensory attribute intensities were dependent variables; judge, cheese, batch, cheese $\times$ batch, and replicate were predictors.

\section{Comparison of Compositional, Chemical, and Texture Profile Analyses to Descriptive Sensory Analysis}

To summarize the data, we conducted a principal components analysis (PCA) with Varimax rotation (XLSTAT; Addinsoft USA, New York, NY) using the mean attribute scores for each cheese. We selected sensory attributes that differed significantly among the cheeses and that had at least one mean score greater than 1.0 for inclusion in the PCA. Instrumental texture and chemical measurements that differed significantly among the cheeses were included as supplemental variables. Correlations between the means of compositional and chemical measurements with significant differences between treatments and descriptive sensory attributes were determined using Pearson correlation $(\alpha=0.05)$ in XLSTAT version 2011.1.04 (Addinsoft USA).

\section{RESULTS AND DISCUSSION}

\section{Compositional, Chemical, and Texture Profile Analyses}

Moisture tended to be lower in treatments containing sea salt compared with analogous treatments containing $\mathrm{NaCl}$, with the exception of the treatment sea salt $+\mathrm{MgCl}_{2}$ (Table 2). Correspondingly, treatments lower in moisture were higher in fat and protein because of less dilution from the moisture. Treatments sea salt + $\mathrm{MgCl}_{2}$ and $\mathrm{NaCl}+\mathrm{MgCl}_{2}$ contained more than $39 \%$ moisture, which is above the legal maximum for Cheddar cheese in the United States. The differences in moisture indicated that less syneresis occurred in cheeses salted with $\mathrm{MgCl}_{2}$, and consequently they had higher moisture contents in the finished cheese. Fitzgerald and Buckley (1985) also found that Cheddar cheese salted with $\mathrm{MgCl}_{2}$ only and an $\mathrm{NaCl}+\mathrm{MgCl}_{2}$ mixture (1:1 mixture) had higher moisture contents than full-sodium control. Higher moisture contents can be explained by an increased hydration of casein proteins due to the effect of replacement salts. Arakawa and Timasheff (1984) reported the effect of $\mathrm{MgCl}_{2}$ on protein solubility was strongly affected by $\mathrm{pH}$, whereas this effect was not observed with $\mathrm{NaCl}$, indicating that hydration was also related to a preferential interaction of $\mathrm{MgCl}_{2}$ with proteins. According to the Hofmeister series, both $\mathrm{Mg}^{2+}$ and $\mathrm{Ca}^{2+}$ should tend to increase the solubility of proteins more than $\mathrm{Na}^{+}$, and could result in more moisture in the cheese and less syneresis (Creighton, 1984). However, increased moisture was not observed in cheeses with $\mathrm{CaCl}_{2}$ in our study. In addition, in a study on the effect of divalent cations on cheese production, Solorza-Feria (2001) found variation in the effect of 2 divalent cations, $\mathrm{Ca}^{2+}$ and $\mathrm{Cd}^{2+}$. Both resulted in more whey expulsion than controls (resulting in cheese with less moisture) and both reduced renneting time, but they noted an inhibitory effect of $\mathrm{Cd}$ on starter cultures. In a study that included the calculation of

Table 3. Water activity $\left(\mathrm{a}_{\mathrm{w}}\right)$ and $\mathrm{pH}$ of Cheddar-style cheese

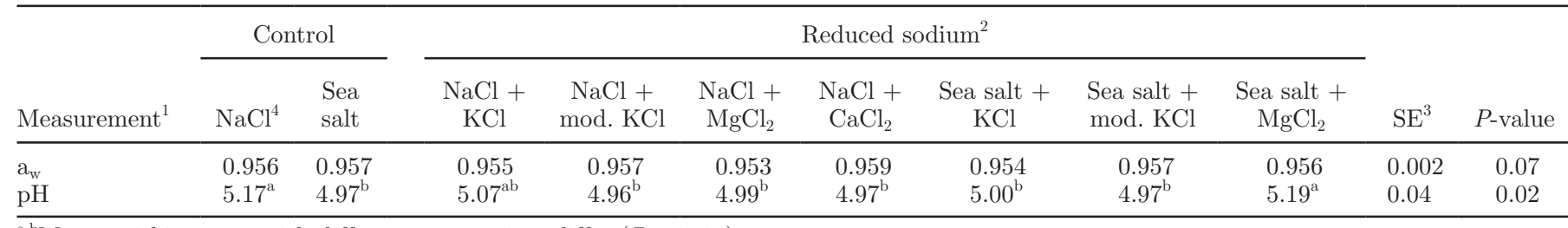

\footnotetext{
a,b Means within a row with different superscripts differ $(P<0.05)$.

${ }^{1}$ Measured at $1 \mathrm{wk}$ of age $\left(\mathrm{a}_{\mathrm{w}}\right)$ or $1 \mathrm{mo}$ of age $(\mathrm{pH})$.

${ }^{2}$ Target: $300 \mathrm{mg}$ of sodium/100 g.

${ }^{3}$ Largest standard error of all treatments is shown for each parameter.

${ }^{4}$ Target: $640 \mathrm{mg}$ of sodium/100 g.
} 


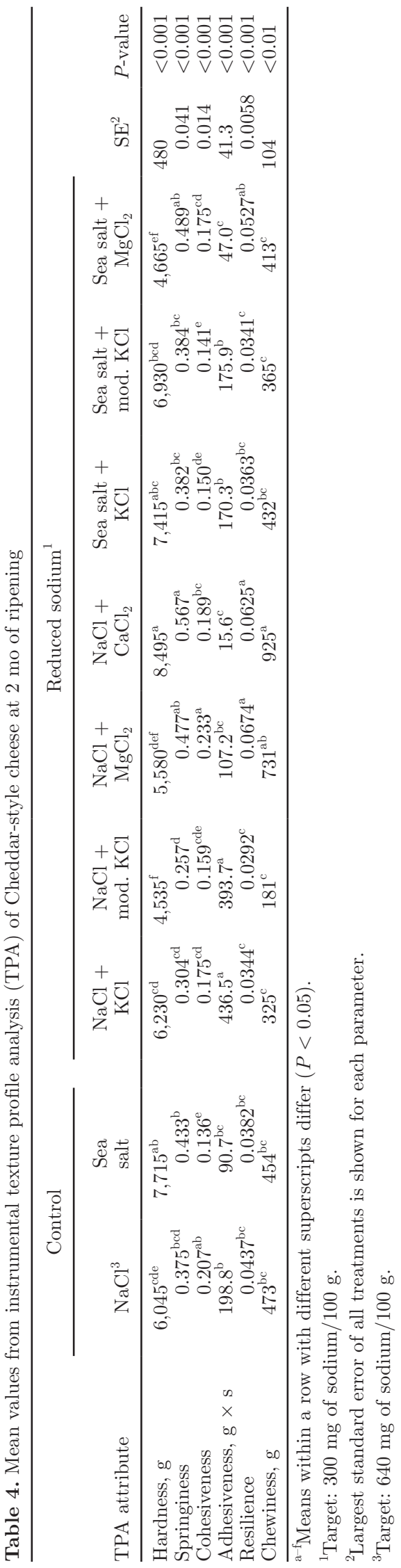

the solubility and speciation of calcium and magnesium in milk, differences were noted in the effect of $\mathrm{pH}$ on solubility (solubility of magnesium did not decrease at $\mathrm{pH}$ above 4, whereas that of calcium did; Nelson et al., 1986). They also noted that complexing of calcium with citrate commenced at a lower $\mathrm{pH}$ and occurred over a broader range than that of magnesium. The differences observed between $\mathrm{MgCl}_{2}$ and $\mathrm{CaCl}_{2}$ observed in our study might be due to a combination of their differing effect on starter cultures, solubility, and interaction with casein in milk.

At a constant salt concentration, one would expect higher $\mathrm{a}_{\mathrm{w}}$ in cheese with a higher moisture content. However, the reduced-sodium cheeses with higher moistures also had higher sodium levels, leading to almost equal sodium-to-moisture ratios. Also interesting was the finding that the sodium concentration of the sea salt control was almost $24 \%$ lower than that of the $\mathrm{NaCl}$ control, even though approximately $25 \%$ more sea salt was added, which should have brought the levels close to parity. During the salting process, moisture is expelled from the cheese and a percentage of salt is lost to the whey. Additional salt is lost when the curd is compressed to form blocks during the pressing step. Higher salting rates are associated with greater whey expulsion and less moisture in the final cheese, and with greater losses of added salt to the whey portion (Sutherland, 1974). Sutherland (1974) reported that salt lost to the whey increased from $33 \%$ of added salt to $50 \%$ when the salting rate was increased from 1.5 to $3.5 \%$ (based on the weight of the curd). Conversely, the moisture of the final cheese decreased from 37.5 to $35 \%$ in the same cheese. Because the amount of moisture expulsion was lower in the cheeses with higher moisture, the loss of salt was also lower.

The $\mathrm{pH}$ of the cheeses ranged from 4.96 to 5.19 at 1 mo of age (Table 3). The reduced-sodium cheeses were lower in $\mathrm{pH}$ than the full-sodium control, with the exception of $\mathrm{NaCl}+\mathrm{KCl}$ and sea salt $+\mathrm{MgCl}_{2}$ cheeses, indicating that the salt replacers and sea salt did not inhibit the starter cultures as much as $\mathrm{NaCl}$ did. The lower $\mathrm{pH}$ (compared with full-sodium control) in treatments $\mathrm{NaCl}+\mathrm{MgCl}_{2}$ and $\mathrm{NaCl}+\mathrm{CaCl}_{2}$ is supported by Fitzgerald and Buckley (1985), who observed a lower $\mathrm{pH}$ in Cheddar cheeses salted with $\mathrm{MgCl}_{2}$ and $\mathrm{CaCl}_{2}$, both with and without $\mathrm{NaCl}$. The lower $\mathrm{pH}$ in cheese with $\mathrm{KCl}$ is also supported by Reddy and Marth (1995), who found the $\mathrm{pH}$ to be lower in 3-d-old Cheddar with various $\mathrm{NaCl}+\mathrm{KCl}$ mixtures. Other studies in Cheddar (Lindsay et al., 1982; Fitzgerald and Buckley, 1985) and Mozzarella (Ayyash and Shah, 2011a) contradict our results, in that they report that cheese with various $\mathrm{NaCl}+\mathrm{KCl}$ mixtures resulted in similar or higher $\mathrm{pH}$ compared with control. 
Table 5. Mean values of descriptive sensory analysis of Cheddar-style cheese at 6 mo of age ${ }^{1}$

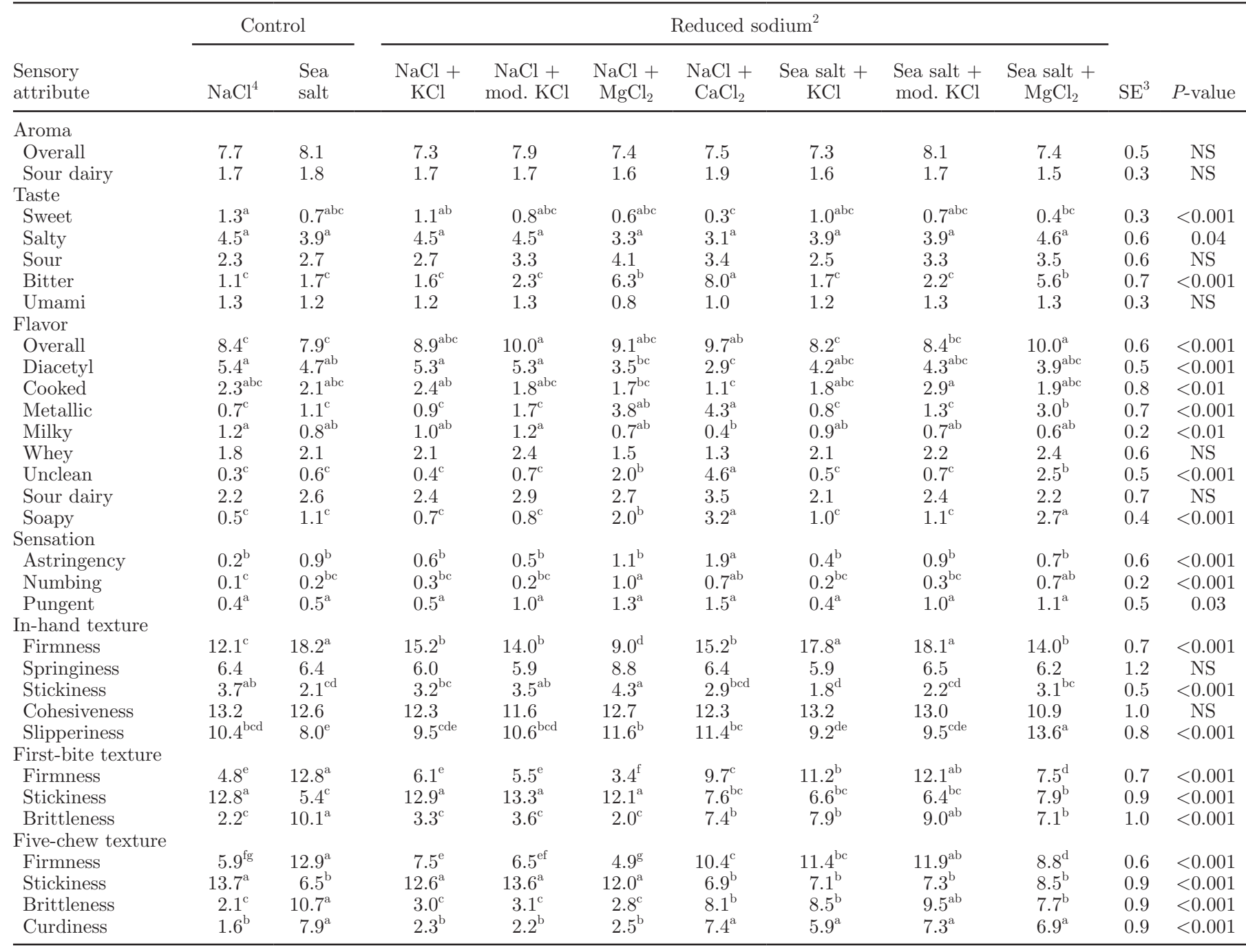

${ }^{\mathrm{a}-\mathrm{g}}$ Means within a row with different superscripts differ $(P<0.05)$.

${ }^{1}$ Only attributes with significant differences between treatments $(\alpha=0.05)$ and means greater than 1 (for at least one treatment) at 1 or 6 mo of age are shown.

${ }^{2}$ Target: $300 \mathrm{mg}$ of sodium/100 g.

${ }^{3}$ Largest standard error of all treatments is shown for each parameter.

${ }^{4}$ Target: $640 \mathrm{mg}$ of sodium/100 g.

NS $=$ No significant differences between treatments $(\alpha=0.05)$.

Differences in the response of bacteria to activity inhibition when exposed to sodium replacement salts have been investigated. Bautista-Gallego et al. (2008) found that $\mathrm{CaCl}_{2}$ inhibited the growth of Lactobacillus pentosus similarly to $\mathrm{NaCl}$, but $\mathrm{KCl}$ and $\mathrm{MgCl}_{2}$ were less inhibitory. In a study on the effect of cations on the activity of $\beta$-galactosidases, including those from Lactococcus lactis ssp. lactis, Garman et al. (1996) found that equimolar concentrations of $\mathrm{K}^{+}$stimulated the activity of the purified enzyme more than $\mathrm{Na}^{+}$and $\mathrm{Mg}^{2+}$. Enzymes sourced from other lactic cultures they studied showed a similar effect in regards to $\mathrm{K}^{+}$stimulating the most, with the exception of $\beta$-galactosidase from Lactobacillus delbrueckii ssp. bulgaricus, where $\mathrm{Na}^{+}$had the greatest stimulatory effect. This could account for differences observed in $\mathrm{pH}$ in our study as a result of acid production due to the utilization of lactose by the cultures.

The instrumental hardness values measured at 2 mo of ripening of the treatments with sea salt were higher than in cheeses containing $\mathrm{NaCl}$, with the exception of $\mathrm{NaCl}+\mathrm{CaCl}_{2}$, which was the hardest, as shown in Table 4. The sea salt used in this study contained sodium, magnesium, and potassium as both chloride- 


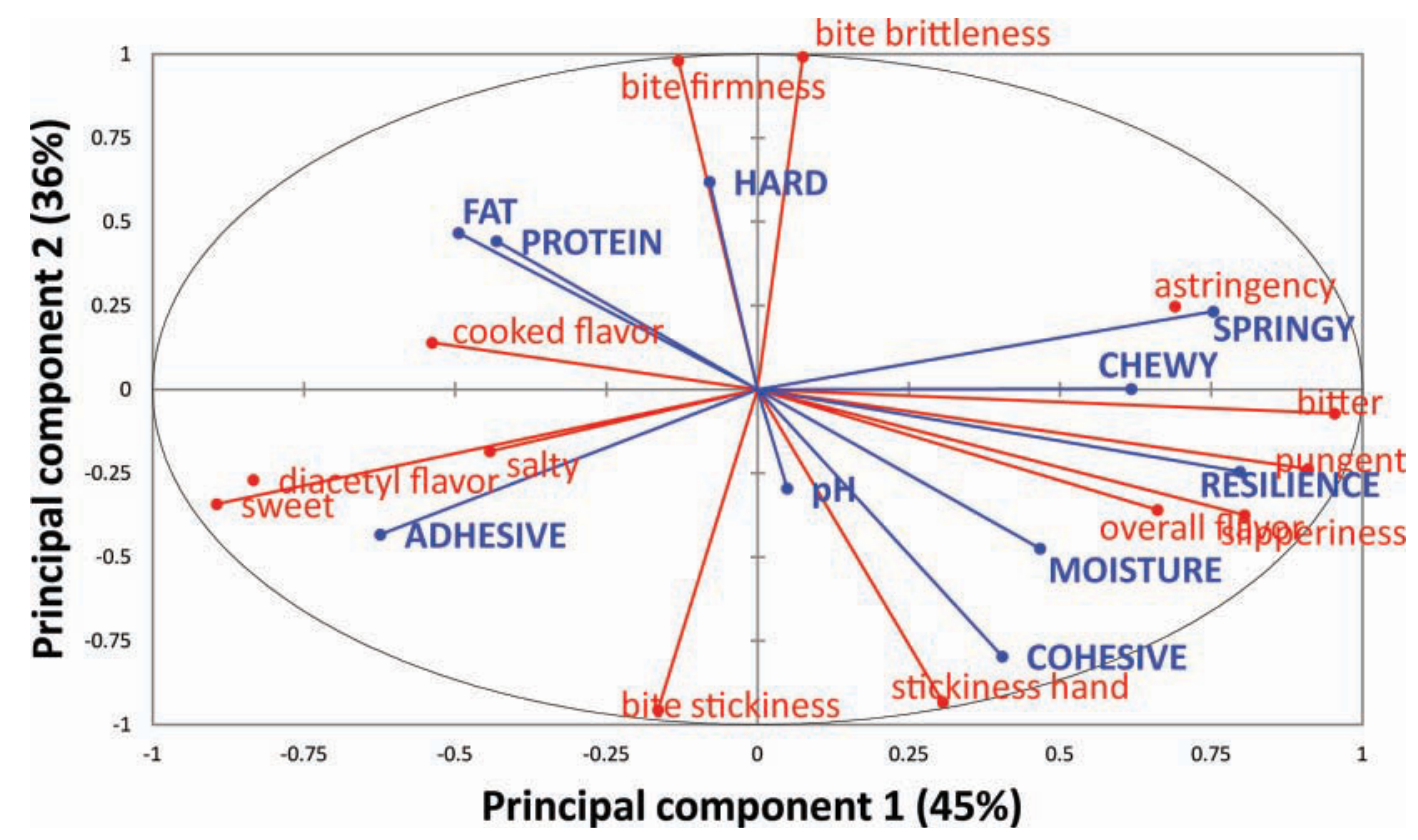

Figure 2. Sensory attributes (lowercase) and instrumental vectors (uppercase) from the principal components analysis (PCA) for components 1 (abscissa) and 2 (ordinate). The PCA was computed over all judges $(n=9)$, products, and sensory replicates for the cheese treatments. Only sensory attributes that had at least one mean score $\geq 1.0$ and that discriminated significantly among the cheeses were included in the PCA. The first component (horizontal axis) correlated $>0.9$ with the following attributes: bitter, metallic, earthy, unclean, soapy, and numbing. Those attributes fall toward the right side of the plot. Component 1 explained $45 \%$ of the variability in the data set. Component 2 (vertical axis) was highly positively correlated $(>0.9)$ with firmness, brittleness, and curdiness (those attributes fall toward the top of the plot), and negatively correlated with stickiness. Component 2 explained an additional $36 \%$ of the variability. To minimize clutter on this plot we removed some of the sensory attributes that correlated highly ( $\mathrm{r}>0.9$ ) with others. Bitter represents metallic, earthy, unclean, soapy, and numbing; diacetyl represents milky; astringency represents fermented; bite firmness represents 5-chew hand firmness and firmness; bite brittleness represents 5-chew brittleness and curdiness; bite stickiness represents 5-chew stickiness. Color version available in the online PDF.

and sulfate-based salts. This different composition from straight $\mathrm{NaCl}$ could have been responsible for the difference in texture, because sulfate and chloride salts (in the case of $\mathrm{Mg}$ ) differ in protein hydration properties (Arakawa and Timasheff, 1984). The increased hardness of treatment $\mathrm{NaCl}+\mathrm{CaCl}_{2}$ is supported by Pastorino et al. (2003), who found that the hardness of cheese similar to low-moisture part-skim Mozzarella increased with an increased concentration of calcium resulting from an injection with a $40 \%$ (wt/wt) $\mathrm{CaCl}_{2}$ solution after pressing. The increased hardness we observed was not supported by the report of Fitzgerald and Buckley (1985), however. They observed lower hardness and firmness in Cheddar cheese salted with $\mathrm{CaCl}_{2}$ only and with a $\mathrm{NaCl}+\mathrm{CaCl}_{2}$ mixture. Cheese made with $\mathrm{NaCl}+\mathrm{CaCl}_{2}$ in our study was also more springy, less adhesive, and more chewy than control cheese. Treatments with $\mathrm{MgCl}_{2}$ were generally less hard than other treatments, with the exception of $\mathrm{NaCl}$-modified $\mathrm{KCl}$. The reduction in instrumental firmness corroborates reports by Lefier et al. (1987) and Chamba and Debry (1994) in reduced-sodium Gruyère and Emmental, when $\mathrm{MgCl}_{2}$ was used to replace sodium in the brine solution. Treatments with KCl generally had similar in- strumental texture values to controls, except for lower cohesiveness and higher adhesiveness in treatments $\mathrm{NaCl}+\mathrm{KCl}$ and $\mathrm{NaCl}+$ modified $\mathrm{KCl}$, respectively. The similarity in instrumental texture is in agreement with Fitzgerald and Buckley (1985) and Katsiari et al. (1997, 1998), who found no significant difference in instrumental textural properties due to $\mathrm{KCl}$ in Cheddar, feta, and Kefalograviera cheeses, respectively.

\section{Descriptive Sensory Analysis}

Numerous sensory differences were observed between treatments, as shown in Table 5. Two principal components defined most $(81 \%)$ of the variation in sensory attributes among the cheeses (Figure 2). The first component (horizontal axes in Figures 2 and 3) correlated positively with bitter, metallic, earthy, unclean, soapy, and numbing. Samples with $\mathrm{CaCl}_{2}$ and $\mathrm{MgCl}_{2}$ scored highly on this component (Figure 3 ). The first component correlated negatively with diacetyl, milky, and cooked flavor; samples with sea salt, $\mathrm{NaCl}$, and $\mathrm{KCl}$ scored negatively on this first component. The second principal component correlated highly with firmness, brittleness, and curdiness. Samples with sea salt scored 


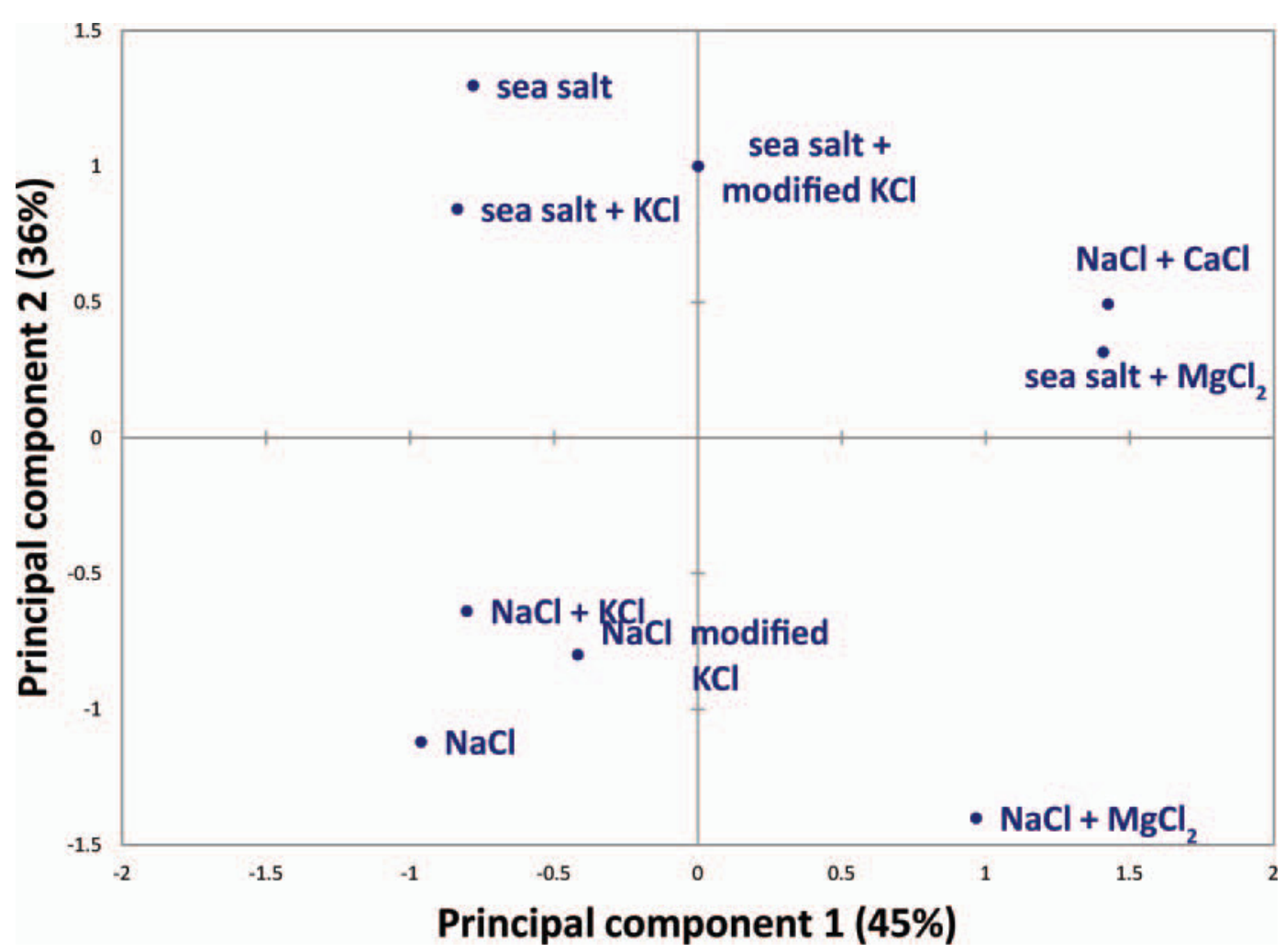

Figure 3. Principal component analysis (PCA) for components 1 and 2 over all judges $(\mathrm{n}=9)$, products, and sensory replicates. Only sensory attributes that had at least one mean score $\geq 1.0$ and that discriminated significantly among the cheeses were included in the PCA. This plot shows the location of the treatments: $\mathrm{NaCl}, \mathrm{NaCl}+\mathrm{CaCl}, \mathrm{NaCl}+\mathrm{KCl}, \mathrm{NaCl}+\mathrm{MgCl}_{2}, \mathrm{NaCl}+$ modified $\mathrm{KCl}$, sea salt, sea salt $+\mathrm{KCl}$, sea salt + $\mathrm{MgCl}_{2}$, and sea salt + modified $\mathrm{KCl}$. The first component (horizontal axis) correlated $>0.9$ with the following attributes: bitter, metallic, earthy, unclean, soapy, and numbing. Component 1 explained $45 \%$ of the variability in the data set. Component 2 (vertical axis) was highly positively correlated (>0.9) with firmness, brittleness, and curdiness, and negatively correlated with stickiness. Component 2 explained an additional $36 \%$ of the variability. Color version available in the online PDF.

high on this component. The second principal component correlated negatively with stickiness; samples containing $\mathrm{NaCl}$ scored negatively on this second component. Cheeses containing $\mathrm{NaCl}+\mathrm{KCl}$ and $\mathrm{NaCl}+$ modified $\mathrm{KCl}$ positioned closest to the control $\mathrm{NaCl}$ in Figure 3, indicating that they had sensory attributes more similar to those of the control than did the other cheeses. These findings agree with those reported by Fitzgerald and Buckley (1985) concerning $\mathrm{MgCl}_{2}$ and $\mathrm{CaCl}_{2}$. Cheddar cheese salted only with $\mathrm{MgCl}_{2}$ or $\mathrm{CaCl}_{2}$ was not included in their sensory evaluation due to a reported extreme bitterness, and cheese salted with a 1:1 molar ratio mixture of $\mathrm{NaCl}$ and $\mathrm{MgCl}_{2}$ or $\mathrm{CaCl}_{2}$ was found to be bitter and metallic.

Cheeses containing $\mathrm{KCl}$ and modified $\mathrm{KCl}$, as described in the principal component plot, did not vary significantly from controls in terms of bitter and salty flavor intensities. This is in contrast to the study of Lindsay et al. (1982), which reported that reduced- and low-sodium Cheddar cheese with $\mathrm{KCl}$ was less salty and more bitter than reduced- and low- $\mathrm{NaCl}$ cheese that did not have $\mathrm{KCl}$ at 6 mo of age. The reduced and low $\mathrm{NaCl}$ cheese in the latter study had both less $\mathrm{NaCl}$ and less $\mathrm{KCl}$ than cheese in our study. Thus, the $\mathrm{a}_{\mathrm{w}}$ of the cheeses between the 2 studies, as well as cheese ripening characteristics, would be expected to differ.

\section{CONCLUSIONS}

Despite achieving equivalent $\mathrm{a}_{\mathrm{w}}$ among treatments, the various salt and salt replacers had different effects on cheese properties. Differences observed in moisture and $\mathrm{pH}$ indicate different effects on cheese culture growth and metabolism and on the solubility of milk proteins. The use of $\mathrm{CaCl}_{2}$ and $\mathrm{MgCl}_{2}$ to reduce sodium in Cheddar-style cheese resulted in flavor differences compared with the full-sodium control, and these flavors (bitter, metallic, earthy, unclean, soapy, and numbing) would not be desirable in high-quality cheese. The reduced-sodium sea salt used in this study resulted in firmer, more brittle, and less sticky cheese compared with $\mathrm{NaCl}$. Cheese made with $\mathrm{NaCl}+\mathrm{KCl}$ and $\mathrm{NaCl}+$ 
modified $\mathrm{KCl}$ were similar to cheeses made with $\mathrm{NaCl}$ in most respects. This indicates that $\mathrm{KCl}$ can be used successfully to achieve large reductions in sodium when replacing a portion of the $\mathrm{NaCl}$ in Cheddar cheese.

\section{ACKNOWLEDGMENTS}

Funding was provided by the Dairy Research Institute, managed by Dairy Management Inc. (Rosemont, IL). We thank the funder and companies who supplied salt replacer and cheese making ingredients. The use of trade names in this publication neither implies endorsement by the funding organization, the University of Minnesota or the researchers, nor criticism of ones we did not evaluate.

\section{REFERENCES}

Agarwal, S., D. McCoy, W. Graves, P. D. Gerard, and S. Clark. 2011. Sodium content in retail Cheddar, Mozzarella, and process cheeses varies considerably in the United States. J. Dairy Sci. 94:16051615.

Aly, M. E. 1995. An attempt for producing low-sodium feta-type cheese. Food Chem. 52:295-299.

Anderson, C. A. M., L. J. Appel, N. Okuda, I. J. Brown, Q. E. Chan, L. C. Zhao, H. Ueshima, H. Kesteloot, K. Miura, J. D. Curb, K. Yoshita, P. Elliott, M. E. Yamamoto, and J. Stamler. 2010. Dietary sources of sodium in China, Japan, the United Kingdom, and the United States, women and men aged 40 to 59 years: The INTERMAP study. J. Am. Diet. Assoc. 110:736-745.

Appel, L. J., M. W. Brands, S. R. Daniels, N. Karanja, P. J. Elmer, and F. M. Sacks. 2006. Dietary approaches to prevent and treat hypertension-A scientific statement from the American Heart Association. Hypertension 47:296-308.

Arakawa, T., and S. N. Timasheff. 1984. Mechanism of protein salting in and salting out by divalent cation salts: Balance between hydration and salt binding. Biochemistry 23:5912-5923.

ASTM. 2010. ASTM Standard E544: Standard practices for referencing suprathreshold odor intensity. ASTM International, West Conshohocken, PA.

Ayyash, M. M., and N. P. Shah. 2011a. The effect of substitution of $\mathrm{NaCl}$ with $\mathrm{KCl}$ on chemical composition and functional properties of low-moisture Mozzarella cheese. J. Dairy Sci. 94:3761-3768.

Ayyash, M. M., and N. P. Shah. 2011b. Proteolysis of low-moisture Mozzarella cheese as affected by substitution of $\mathrm{NaCl}$ with $\mathrm{KCl}$. J. Dairy Sci. 94:3769-3777.

Bautista-Gallego, J., F. N. Arroyo-Lopez, M. C. Duran-Quintana, and A. Garrido-Fernandez. 2008. Individual effects of sodium, potassium, calcium, and magnesium chloride salts on lactobacillus pentosus and Saccharomyces cerevisiae growth. J. Food Prot. 71:1412-1421.

Bourne, M. C. 1978. Texture profile analysis. Food Technol. 32:62-66.

Chamba, J. F., and G. Debry. 1994. Caractéristiques et acceptabilité d'emmentals hyposodés. Sci. Aliments 14:335-348.

Cotugna, N., and S. Wolpert. 2011. Sodium recommendations for special populations and the resulting implications. J. Community Health 36:874-882.

Creighton, T. E. 1984. Proteins: Structures and Molecular Properties. 2nd ed. W. H. Freeman and Company, New York, NY.

FDA. 2011. Nutrition labeling of food. 21 CFR 101.9(c)(9) http:// www.accessdata.fda.gov/scripts/cdrh/cfdocs/cfcfr/CFRSearch. $\mathrm{cfm} ? \mathrm{fr}=101.9$.

Fitzgerald, E., and J. Buckley. 1985. Effect of total and partial substitution of sodium chloride on the quality of Cheddar cheese. J. Dairy Sci. 68:3127-3134.
Garman, J., T. Coolbear, and J. Smart. 1996. The effect of cations on the hydrolysis of lactose and the transferase reactions catalysed by beta-galactosidase from six strains of lactic acid bacteria. Appl. Microbiol. Biotechnol. 46:22-27.

Grummer, J., and T. C. Schoenfuss. 2011. Determining salt concentrations for equivalent water activity in reduced-sodium cheese by use of a model system. J. Dairy Sci. 94:4360-4365.

Guinee, T. P. 2004. Salting and the role of salt in cheese. Int. J. Dairy Technol. 57:99-109.

IDF. 2007. Milk and milk products: Determination of sodium, potassium, calcium and magnesium contents-Method by flame atomic absorption spectrometric method. Joint Standard IDF 119/ISO 8070. International Dairy Federation, Brussels, Belgium, and International Organisation for Standardisation, Geneva, Switzerland.

Jacobson, M. F. 2005. Salt: The forgotten killer. Center for Science in the Public Interest, Washington, DC.

Johnson, M. E., R. Kapoor, D. J. McMahon, D. R. McCoy, and R. G. Narasimmon. 2009. Reduction of sodium and fat levels in natural and processed cheeses: Scientific and technological aspects. Comp. Rev. Food Sci. Food Saf. 8:252-268.

Katsiari, M. C., E. Alichanidis, L. P. Voutsinas, and I. G. Roussis. 2001. Proteolysis in reduced sodium Kefalograviera cheese made by partial replacement of $\mathrm{NaCl}$ with $\mathrm{KCl}$. Food Chem. 73:31-43.

Katsiari, M. C., L. P. Voutsinas, E. Alichanidis, and I. G. Roussis. 1997. Reduction of sodium content in feta cheese by partial substitution of $\mathrm{NaCl}$ by KCl. Int. Dairy J. 7:465-472.

Katsiari, M. C., L. P. Voutsinas, E. Alichanidis, and I. G. Roussis 1998. Manufacture of Kefalograviera cheese with less sodium by partial replacement of $\mathrm{NaCl}$ with $\mathrm{KCl}$. Food Chem. 61:63-70.

Kira, C. S., F. D. Maio, and V. A. Maihara. 2004. Comparison of partial digestion procedures for determination of $\mathrm{Ca}, \mathrm{Cr}, \mathrm{Cu}, \mathrm{Ce}$, $\mathrm{K}, \mathrm{Cg}, \mathrm{Mn}, \mathrm{Na}, \mathrm{P}$, and $\mathrm{Zn}$ in milk by inductively coupled plasmaoptical emission spectrometry. J. AOAC Int. 87:151-156.

Lefier, D., R. Grappin, G. Grosclaude, and G. Curtat. 1987. Sensory properties and nutritional quality of low-sodium Gruyere cheese. Lait 67:451-464.

Lindsay, R. C., S. M. Hargett, and C. S. Bush. 1982. Effect of sodiumpotassium (1:1) chloride and low sodium-chloride concentrations on quality of Cheddar cheese. J. Dairy Sci. 65:360-370.

Nelson, L. S., F. A. Jacobs, J. G. Brushmiller, and R. W. Ames. 1986. Effect of $\mathrm{pH}$ on the speciation and solubility of divalent metals in human and bovine milks. J. Inorg. Biochem. 26:153-168.

Pastorino, A. J., N. P. Ricks, C. L. Hansen, and D. J. McMahon. 2003. Effect of calcium and water injection on structure-function relationships of cheese. J. Dairy Sci. 86:105-113.

Pontet, C., M. Murray, and Z. Vickers. 2010. Experimentally created intensity scales for the five basic tastes: Sweet, sour, salty, bitter and umami. Abstract 160-12, Page 101 in Book of Abstracts, IFT Annual Meeting, Chicago, IL. Institute of Food Technologists, Chicago, IL.

Reddy, K. A., and E. H. Marth. 1995. Microflora of Cheddar cheese made with sodium-chloride, potassium-chloride, or mixtures of sodium and potassium-chloride. J. Food Prot. 58:54-61.

Richardson, G. H. 1985. Standard Methods for the Examination of Dairy Products. 15th ed. American Public Health Association, Washington, DC.

Solorza-Feria, J. 2001. Study of the changes in cheese making parameters of skim milk with divalent cations addition. Food Technol. Biotechnol. 39:115-121.

Sutherland, B. J. 1974. Control of salt absorption and whey drainage in Cheddar cheese manufacture. Aust. J. Dairy Technol. 29:86-93.

USDA. 2011. National Nutrient Database for Standard Reference. USDA Agricultural Research Service Nutrient Data Laboratory. Accessed Jan. 28, 2011. http://www.nal.usda.gov/fnic/foodcomp/ search/.

Wehr, H. M., and J. F. Frank. 2004. Standard Methods for the Examination of Dairy Products. 17th ed. American Public Health Association, Washington, DC. 